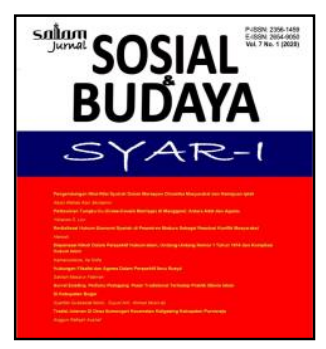

P-ISSN: 2356-1459. E-ISSN: 2654-9050

Vol. 8 No. 1 (2021), pp. 173-190

DOI: 10.15408/sjsbs.v8i1.19426

http://journal.uinjkt.ac.id/index.php/salam/index

\title{
Kemitraan antara Petani Kopi Rakyat dengan Perusahaan (Studi Kasus Kintamani)*
}

\author{
Ginanjar Dwi Cahyanto', Agung Wibowo ${ }^{2}$, Putri Permatasari ${ }^{3}$ \\ Universitas Sebelas Maret \\ d. \\ $10.15408 /$ sjsbs.v8i1.19426
}

\begin{abstract}
The partnership between the Kintamani people's coffee farmers and the company is expected to absorb overall production as well as increase the coffee production of the farmers and be mutually beneficial. PT. Perkebunan Nusantara XII is a company that is a partner of the Kintamani people's coffee farmers, precisely in the Blawan Bondowoso Plantation by forming a core plasma partnership pattern. This study aims to describe the partnership conditions that exist between the Kintamani people's coffee farmers and the company. The qualitative data analysis technique is done by collecting data until it is saturated and then conveyed interactively. Research showed that there were three parties involved between the company, smallholder coffee farmers and BNI. The company as the core company provides assistance, procurement and purchasing facilities to smallholder coffee farmers as a plasma. In addition, the smallholder coffee farmers as plasma have an obligation to provide their coffee production to the nucleus company. The purchase of coffee production by the core company involves BNI as the party that distributes capital loans in the form of People's Business Credit (KUR) to plasma. The impact of partnerships with companies is felt by smallholder coffee farmers, such as the smooth marketing of coffee. The hope of partnership farmers can be continuous and implemented in the long term.
\end{abstract}

Keywords: Coffee, Corporate, Nucleus-plasma Pattern, Partnership, Smallholder Coffee Farmers Abstrak

Kemitraan antara petani kopi rakyat Kintamani dengan perusahaan diharapkan dapat menyerap produksi secara keseluruhan sekaligus peningkatan produksi kopi petani dan bisa saling menguntungkan. PT. Perkebunan Nusantara XII merupakan perusahaan yang menjadi mitra petani kopi rakyat Kintamani tepatnya di Kebun Blawan Bondowoso dengan membentuk suatu pola kemitraan inti plasma. Penelitian ini bertujuan mendeskripsikan kondisi kemitraan yang terjalin antara petani kopi rakyat Kintamani dengan perusahaan. Teknik analisis data kualitatif dilakukan dengan mengumpulkan data hingga jenuh kemudian disampaikan secara interaktif. Penelitian menunjukkan terbentuk tiga pihak yang berhubungan antara perusahaan, petani kopi rakyat dan BNI. Perusahaan sebagai perusahaan inti memberikan fasilitas pendampingan, pengadaan dan pembelian kepada petani kopi rakyat sebagai plasmanya. Di samping itu petani kopi rakyat sebagai plasma memiliki kewajiban memberikan hasil produksi kopinya kepada perusahaan inti. Pembelian hasil produksi kopi oleh perusahaan inti melibatkan BNI sebagai pihak yang menyalurkan pinjaman modal berupa Kredit Usaha Rakyat (KUR) kepada plasma. Dampak kemitraan dengan perusahaan yang dirasakan petani kopi rakyat seperti lancarnya pemasaran kopi. Harapan petani kemitraan bisa kontinu dan dilaksanakan dalam jangka panjang.

Kata kunci: Kopi, Kemitraan, Perusahaan, Petani Kopi Rakyat, Pola Inti-Plasma

${ }^{*}$ Received: January 16, 2021, Revision: January 20, 2021, Published: February 08, 2021.

${ }^{1}$ Ginanjar Dwi Cahyanto adalah Peneliti pada Program Studi Penyuluhan dan Komunikasi Pertanian, Program Sarjana Universitas Sebelas Maret. Email: ginanjar.dc98@gmail.com

${ }^{2}$ Agung Wibowo adalah Peneliti pada Program Studi Penyuluhan dan Komunikasi Pertanian, Program Sarjana Universitas Sebelas Maret. Email: agungwibowo@staff.uns.ac.id

${ }^{3}$ Putri Permatasari adalah Peneliti pada Program Studi Penyuluhan dan Komunikasi Pertanian, Program Sarjana Universitas Sebelas Maret. Email: putripermatasari@staff.uns.ac.id 


\section{A. PENDAHULUAN}

Kopi merupakan komoditas penting dalam perekonomian Indonesia karena bernilai ekonomi yang relatif tinggi di pasar dunia. Indonesia menjadi pengekspor kopi terbesar keempat dunia dengan produksi yang mencapai 660.000 ton. Tahun 2016 kopi merupakan komoditas yang memiliki nilai ekspor perdagangan mencapai 1.01 milyar US\$ dari total nilai perdagangan yang mencapai 25.58 milyar US\$ yang artinya berkontribusi 3.94\%. ${ }^{5}$ Kegiatan ekspor didukung dengan produksi kopi Indonesia pada tahun 2018 mencapai 722,46 ton. ${ }^{6}$ Kopi tersebar di berbagai wilayah Indonesia terutama Sulawesi, Jawa, Sumatera, Bali, dan Nusa Tenggara dengan sekitar 95\% dari luas areal tersebut merupakan perkebunan yang dimiliki rakyat.7

Bali merupakan salah satu daerah penghasil kopi arabika dan robusta terbesar di Indonesia. Jenis kopi arabika di Bali lebih banyak diusahakan dibanding kopi robusta. Kopi menjadi komoditas pertanian unggulan di Bali karena memiliki keunggulan komparatif, keunggulan bersaing, keunggulan spesifik lokasi dan keunggulan strategis. ${ }^{8}$ Kintamani merupakan salah satu daerah di Kabupaten Bangli menjadi sentra produksi dan ikon kopi arabika Bali. Pada tahun 2014 areal kopi arabika Kabupaten Bangli 6.600 ha dari total 13.150 ha total areal kopi arabika di Bali. Dari sisi produksi, Kabupaten Bangli juga menjadi daerah penghasil kopi arabika terbesar di Bali dengan jumlah produksi 2.477 ton, sedangkan areal kopi arabika di dua kabupaten penghasil utama lainnya yakni Kabupaten Buleleng tercatat 2.714 hektar dengan produksi 932 ton, dan Kabupaten Badung 1.413 ha dengan produksi 531 ton. ${ }^{9}$

Proses manajemen usaha tani kopi petani rakyat Kintamani dilakukan secara individu maupun berkelompok atau yang disebut dengan subak. Petani kopi rakyat Kintamani menerapkan budidaya dengan sistem organik menggunakan pupuk kandang dan kompos dalam segi pemupukan. Lahan yang digunakan petani milik pribadi bukan menyewa milik Perhutani seperti yang banyak dilakukan oleh petani kopi rakyat di Jawa Timur. Budidaya kopi dengan sistem organik tentunya berdampak baik bagi hasil kopi yang didapatkan. Kopi arabika yang dihasilkan memiliki kualitas

${ }^{4}$ International Coffee Organization. (2016). Monthly Coffee Market Report. 13 September 2019, dapat diakses online di http://www.ico.org.

${ }^{5}$ Pusat Data dan Sistem Informasi Pertanian. (2017). Outlook kopi (komoditas pertanian sub sektor perkebunan). Jakarta.

${ }^{6}$ Pusat Data dan Sistem Informasi Pertanian. (2019). Outlook kopi (komoditas pertanian sub sektor perkebunan). Jakarta.

${ }^{7}$ Yahmadi, M. (2007). Rangkaian perkembangan dan permasalahan budidaya dan pengolahan kopi di Imdonesia. Surabaya: AEKI.

${ }^{8}$ Widia, IW; Duniaji, AS. (2016). Laporan pelaksanaan rencana aksi pengembangan industri agro kopi di Propinsi Bali tahun 2016. Bali: Dinas Perindustrian dan Perdagangan Propinsi Bali dan Fakultas Teknologi Pertanian Universitas Udayana.

9 Dinas Perkebunan Bali. (2015). Kopi Arabika Kintamani Masuk Unggulan Komoditi Nasional [Internet]. Available from: http://www.disbun.baliprov.go.id/berita/detail/74-kopi-arabika-kintamanimasukunggulan-komoditi-nasional 
yang baik dan memiliki cita rasa yang unik yaitu beraroma jeruk dengan rasa sedikit asam. ${ }^{10}$ Mutu kopi Kintamani juga sudah terbilang mendunia.

Saat panen raya, produksi kopi Kintamani terbilang cukup tinggi dan memerlukan kesiapan pasar untuk penjualan. Selama ini pasar kopi Kintamani mengandalkan pengepul dari sekitar Kintamani, Singaraja atau yang lain namun belum bisa menyerap semua bahan baku yang dimiliki petani. Biasanya pengepul lokal membatasi pembelian ke petani. Pembatasan tersebut menyebabkan petani harus mencari pasar lagi agar dapat terserap semua. Hal tersebut dapat menyebabkan harga kopi dipermainkan oleh pengepul. Penjualan ke pengepul lokal cukup sulit, harga yang ditawarkan sangat rendah kurang lebih sebesar Rp5000/kg. Minimnya pasar lokal dan harga kopi yang rendah karena ketidaksanggupan pengepul lokal dalam menyerap kopi petani dengan kapasitas besar membuat petani kopi rakyat Kintamani membutuhkan pasar yang dapat menyerap semua produksi kopi dengan harga yang layak.

Maka dibutuhkan kemitraan antara petani dengan perusahaan agar dapat menyerap produksi secara keseluruhan sekaligus peningkatan produksi kopi petani. Kemitraan yang dilakukan diharapkan bisa saling menguntungkan. PT. Perkebunan Nusantara XII merupakan perusahaan yang menjadi mitra petani kopi rakyat Kintamani Bali tepatnya di Kebun Blawan Bondowoso dengan membentuk suatu pola kemitraan inti plasma. Keterbatasan petani kopi rakyat dataran tinggi Ijen membuat Kebun Blawan mengambil kebijakan dengan memilih wilayah plasma di Kintamani Bali. Keputusan tersebut bertujuan untuk mengoptimalkan suplai produksi kopi kepada Kebun Kalisat Jampit, Kebun Pancur Angkrek dan Kayumas di dataran tinggi Ijen Bondowoso. Penelitian ini bertujuan mendeskripsikan kondisi kemitraan yang terjalin antara petani kopi rakyat Kintamani dengan Kebun Blawan.

\section{B. Metode penelitian}

Metode dasar penelitian menggunakan metode deskriptif yang menekankan pengumpulan fakta dan identifikasi data dengan menggambarkan atau mendeskripsikan objek penelitian berdasarkan fakta yang ada di lapangan. ${ }^{11}$ Penelitian ini menggunakan pendekatan kualitatif dengan memperbanyak informasi yang didapatkan, mencari hubungan yang ada, membandingkan, menemukan pola atas dasar data aslinya. Analisis data menghasilkan situasi atau kondisi yang diteliti disajikan dalam bentuk uraian naratif. ${ }^{12}$ Strategi yang digunakan dalam penelitian ini yaitu studi kasus dengan proses pengumpulan informasi dan data secara mendalam, mendetail, intensif, holistik dan sistematis berdasarkan sumber informasi orang,

${ }^{10}$ Mawardi S; Wibawa A; Avelino J; Perriot J-J; Jacquet M; Sautier D; De Taffin G; Sallée B; Lelong C; Ribeyre F. (2005). Developing a geographical indication for Arabica coffee in Bali: Description of the "Terroir" of Kintamani. 20th Int Conf Coffee Sci.: 922-928.

${ }^{11}$ Moleong, L., J. (2018). Metodologi penelitian kualitatif. Bandung: PT Remaja Rosdakarya Offset.

12 [DITJEN PMPTK] Direktorat Jenderal Peningkatan Mutu Pendidik dan Tenaga Kependidikan Departemen Pendidikan Nasional. (2008). Pendekatan, Jenis, dan Metode Penelitian Pendidikan. Jakarta. 
kejadian, social setting (latar sosial) atau kelompok itu beroperasi atau berfungsi sesuai dengan konteksnya. ${ }^{13}$

Subjek penelitian ini adalah petani kopi rakyat Kintamani Bali yang bermitra dengan Kebun Blawan. Lokasi penelitian dilaksanakan di Desa Batukaang, Kecamatan Kintamani, Kabupaten Bangli. Teknik analisis data kualitatif dilakukan secara interaktif dan berlangsung secara terus menerus sampai tuntas, sehingga datanya sudah jenuh. Aktivitas dalam analisis data yaitu data reduction, data display dan data conclusion drawing/verification. ${ }^{14}$

\section{HASIL TEMUAN DAN PEMBAHASAN}

\section{Konsep Kemitraan dan Pola Inti Plasma}

Berdasarkan Kamus Besar Bahasa Indonesia (KBBI), mitra diartikan sebagai teman, kawan kerja, ataupun rekan. Sedangkan arti kata kemitraan berarti hubungan yang dilakukan mitra untuk melakukan kerja sama. Arti tersebut diperkuat dengan UU No.20 Tahun 2008 yang menyatakan bahwa kemitraan adalah kerja sama dalam keterkaitan usaha, baik langsung maupun tidak langsung, atas dasar prinsip saling memerlukan, mempercayai, memperkuat, dan menguntungkan yang melibatkan pelaku usaha mikro, kecil dan menengah dengan usaha besar. Kemitraan tentunya memperhatikan tiga prinsip diantaranya saling menguntungkan, saling memerlukan dan saling memperkuat.

Kemitraan merupakan upaya kolaboratif yang bertujuan untuk mengumpulkan dan atau berbagi sumber daya seperti keuangan, kepegawaian, keterampilan, keahlian dan informasi atau pengetahuan. Pendekatan ini menguntungkan kolaborator dan juga memungkinkan mereka untuk fokus pada tujuan bersama. Esensi dari kemitraan cocok dengan hubungan pertukaran sosial. Interaksi sosial seperti saling ketergantungan, kepercayaan, dan komitmen terkait dengan pemain kunci seperti pemasok hulu, pelanggan hilir dan pesaing pasar. ${ }^{15}$

Kemitraan membentuk ikatan kerja sama antara dua pihak atau lebih dalam bentuk persekutuan atas dasar kesepakatan dan satu sama lain saling membutuhkan. Kemitraan tentunya berpeluang untuk meningkatkan perekonomian nasional sekaligus meningkatkan kesejahteraan sehingga memberikan penyelesaian masalah masyarakat. ${ }^{16}$ Terdapat lima bentuk kemitraan antara petani dengan pengusaha besar dalam sistem agribisnis di Indonesia. Bentuk-bentuk kemitraan tersebut terdiri dari dagang umum,

${ }^{13}$ Yusuf, A., M. (2017). Metodologi penelitian kuantitatif, kualitatif \& penelitian gabungan. Jakarta: Prenademedia Group.

${ }^{14}$ Miles, B. Mathew dan Michael Huberman. 1992. Analisis Data Kualitatif Buku Sumber Tentang Metode-metode Baru. Jakarta: UIP.

15 Rathi, D., Given, L., M., \& Forcier, E. (2014). Interorganisational partnership and knowledge sharing: the perspective of Non-Profit Organizations (NPOs). Journal of Knowledge Management. 18(5): 867885 .

${ }^{16}$ Sulistiyani, A., T. (2004). Kemitraan dan model-model pemberdayaan. Yogyakarta: Gava Media. 
sub kontrak, keagenan dan kerja sama operasional agribisnis serta pola kemitraan inti plasma. ${ }^{17}$

Pola kemitraan antara petani sebagian plasma dengan perusahaan sebagai inti dimulai dengan sosialisasi kepada masyarakat untuk menyampaikan landasan dan tujuan. Proses penyerahan lahan diawali dengan mengajukan proposal kepada pihak perusahaan untuk dilakukan pengecekan dan pengukuran. Syarat menjadi petani plasma harus menyediakan lahan sedangkan perusahaan menyediakan sarana produksi dalam bentuk kredit. Kemudian pengukuran yang terdiri dari pihak perusahaan, aparat pemerintah desa dan muspika kecamatan melakukan pengecekan untuk meninjau kebenaran lokasi dan melakukan pengukuran. Setelah dilakukan pengukuran dan pemetaan kemudian diterbitkan peta lokasi. Proses pola kemitraan tertuang dalam perjanjian kontrak pada saat penyerahan lahan yang ditanda tangani kedua belah pihak. Perusahaan menanggung semua biaya pembangunan kebun antara lain biaya pembukaan lahan (land clearing), penyediaan bibit, pupuk serta memberikan jaminan kepastian pasar kepada petani plasma. ${ }^{18}$

Hubungan kemitraan inti plasma antara perusahaan dengan petani atau koperasi unit desa berpeluang menciptakan asimetris informasi, karena kurangnya penguasaan informasi tentang pengelolaan usaha tani. Pada dasarnya konsep kemitraan merupakan konsep kerja sama yang harus memiliki peran yang setara antara kedua belah pihak yang menjadi mitra, sehingga diharapkan adanya partisipasi aktif dari para pihak untuk mencapai tujuan bersama. Kurangnya partisipasi masyarakat dalam skema kemitraan dapat diukur dari faktor internal dan eksternal yang dimiliki. Faktor internal yang dimiliki berkaitan dengan usia, pekerjaan, pendapatan dan tempat tinggal. Kemudian faktor eksternal yaitu Kurangnya informasi yang diterima masyarakat, persyaratan yang sulit dipenuhi dan prosedur yang tidak jelas. Sejauh mana partisipasi petani dalam skema kemitraan dan kerja sama tentunya sangat bergantung pada peran yang diberikan, baik terkait hak maupun kewajiban. Peran atau hak dan kewajiban petani atau koperasi dalam pola kemitraan diatur dalam perjanjian hukum yang disaksikan oleh notaris. ${ }^{19}$

\section{Budidaya Kopi dan Petani Rakyat Kintamani}

Petani kopi rakyat melakukan budidaya kopi jenis arabika karena faktor ketinggian dan suhu lingkungan yang cukup dingin. Ketinggian yang ditanam petani rata-rata $1200 \mathrm{mdpl}$ dan cocok ditanami kopi arabika. Semakin tinggi dataran yang ditanam, semakin baik pula kopi yang dihasilkan. Selain ketinggian, faktor tanah juga mempengaruhi. Secara administratif wilayah penghasil kopi Kintamani meliputi tiga

17 Sumardjo, Sulaksana, J., \& Darmono, W. (2004). Teori dan praktik kemitraan agribisnis. Jakarta. Penebar Swadaya.

${ }^{18}$ Imang, N., Balkis, S, \& Maliki. (2019). Analisis implementasi pola kemitraan dan pendapatan petani plasma kelapa sawit di Kecamatan Bentian Besar Kabupaten Kutai Barat Provinsi Kalimantan Timur. Jurnal Pertanian Terpadu. 7(1): 112-121.

${ }^{19}$ Lukman, I., A., Munawar, I., \& Dwi, B. (2019). Palm oil plantation partnership's performance in Kuantan Singingi Region. The International Journal of Accounting and Business Society. 27 (2): 92-113. 
kabupaten, yaitu Kabupaten Bangli, Kabupaten Badung dan Kabupaten Buleleng. Kawasan tersebut memiliki karakteristik ketinggian tempat, curah hujan, suhu udara, maupun karakteristik tanah yang berpengaruh terhadap citarasa kopi Kintamani. ${ }^{20}$ Ciri khas kopi kintamani diantaranya ukuran biji kopi yang besar, rendemennya tinggi, bisa dibuat campuran kopi lain, citarasa tingkat keasaman tinggi, kepekatan kopinya kental dan kuat serta timbul aroma jeruk pada kopinya.

Hasil penelitian ${ }^{21}$ juga menunjukkan bahwa cita rasa yang terbaik dan unik berdasar atas ketinggian tempat tanam, iklim mikro dan makro serta pengolahan yang dilakukan. Proses pengeringan kopi Kintamani tidak dilakukan di daerah Kintamani, melainkan di daerah Kabupaten Buleleng yang memiliki ketinggian lebih rendah dan dekat ke pantai sehingga suhu udaranya lebih panas. Kombinasi antara agroekosistem dan tindakan budidaya tersebut menghasilkan produk kopi Kintamani yang memiliki cita rasa khas ${ }^{22}$ : (1) bebas dari cacat cita rasa utama, (2) rasa asam jeruk sesuai dengan lama fermentasi, (3) rasa pahit yang rendah, dan (4) mutu dan intensitas aroma yang kuat dengan rasa buah jeruk.

Petani menerapkan budidaya kopi organik menggunakan pupuk kandang dan kompos dalam segi pemupukan. Sumber pupuk kandang dari kotoran sapi sementara pupuk kompos dari sampah daun tanaman kopi. Sumber kotoran sapi berasal dari sapi yang diternakkan setiap petani kopi rakyat. Suburnya tanah membuat budidaya kopi tidak pernah mengalami gagal panen. Kesuburan tanah didukung dengan pemupukan setahun sekali dengan dosis sekitar $10-20 \mathrm{~kg}$ setiap lubang tanaman dan penggemburan. Pupuk kandang memberikan kesuburan pada tanah dibanding pupuk kimia. Petani tidak menggunakan pupuk kimia karena dapat merusak tanaman. Penggunaan pupuk kimia menyebabkan tanah cepat gersang sehingga berdampak pada produksi kopi. Pemberian pupuk kandang dan proses teknik fermentasi berpengaruh terhadap cita rasa dan mutu kopi arabika. Sampai saat ini petani tidak mengajukan sertifikasi kopi organik karena petani menganggap sertifikasi tersebut tidak berpengaruh signifikan terhadap penjualannya. ${ }^{23}$

Suburnya tanah dapat mempermudah penyerapan air yang menjadi salah satu unsur kebutuhan tanah. Ketersediaan air di areal budidaya kopi sekitar Kintamani tergolong melimpah. Hujan yang sering terjadi menyebabkan petani tidak sulit mencari air. Irigasi yang baik menjadi faktor pendukung kesuburan tanah budidaya kopi. Ketika terjadi kekeringan petani bisa langsung adaptif dengan menggunakan sumur bor untuk irigasi. Irigasi pada lahan kebun untuk budidaya sampai saat ini lancar dan tidak ada kendala. Inovasi dilakukan oleh masing-masing petani tanpa melibatkan subak.

Hasil panen masing-masing petani kopi rakyat setiap tahunnya fluktuatif, artinya naik turun. Faktor pemeliharaan yang kurang optimal menjadi penyebab naik

${ }^{20}$ MPIG. 2007. Buku Persyaratan Indikasi Geografis Kopi Arabika Kintamani Bali.

${ }^{21}$ Wahyuni E, Karim A, Anhar A. 2013. Analisis Citarasa Kopi Arabika Oganik pada Beberapa Ketinggian Tempat dan Cara Pengolahannya di Dataran Tinggi Gayo. J Manaj Sumberd Lahan. 2(3).

${ }^{22}$ MPIG. Op.cit

${ }^{23}$ Rubiyo, Kartini L, Agung IMS. 2005. Pengaruh Dosis Pupuk Kandang dan Lama Fermentasi terhadap Mutu Fisik dan Citarasa Kopi Arabika Varietas S 795 di Bali. J Pengkaj dan Pengemb Teknol Pertan. 8:250-260. 
turunnya hasil panen petani kopi rakyat. Sejauh ini program hanya berfokus pada pengembangan mutu kopi petani. Perbanyakan bibit menggunakan sistem cangkok dan belum ada khusus lahan pembibitan yang luas untuk proses penyulaman. Biasanya saat panen kopi, petani melakukan proses pengolahan pasca panen berupa proses fermentasi seperti fullwash, natural, honey dan wine. Namun, kuantitas pengolahan masih tergolong minim karena belum ada tempat yang memadai untuk melakukan proses pengolahan kopi dalam jumlah banyak. Mayoritas petani kopi rakyat di wilayah Kintamani memiliki lahan yang sempit. Maka dari itu petani kopi rakyat lebih memilih memasarkan kopi dengan cepat agar dapat langsung menghasilkan uang. Meskipun begitu, sampai saat ini budidaya kopi yang dilakukan petani sudah dapat mencukupi kebutuhan anak dan keluarga.

Terkait kebutuhan hidup selain dari pemasaran kopi, petani sudah dapat tercukupi dengan tambahan pendapatan dari hasil tumpangsari. Mayoritas petani kopi rakyat menanam kopi dengan tanaman penaung jeruk sekaligus tumpangsari. Penanaman jeruk dilakukan sebelum bibit kopi di tanam. Adanya tanaman penaung berupa jeruk berdampak positif pada tanaman kopi. Selain itu, petani kopi rakyat yang memiliki lahan tumpangsari berupa sayuran masih bisa memasarkan hasilnya ke pasar meskipun dengan harga yang rendah. Sayuran masih bisa mudah terjual karena merupakan kebutuhan primer berbeda dengan kopi. Petani juga memiliki tabungan berupa investasi hewan ternak berupa sapi atau babi. Setiap petani paling sedikit memiliki dua ekor sapi. Selain dimanfaatkan kotoran sapinya, beberapa petani juga melakukan ternak sapi dengan sistem jual beli. Terdapat kandang sapi disetiap kebun milik petani kopi rakyat. Investasi yang dimiliki petani kopi rakyat berupa lahan budidaya tanaman dan alat diberikan oleh Pusat Penelitian Kopi dan Kakao Jember melalui subak.

Petani kopi rakyat Kintamani selama ini melakukan budidaya dengan pengalaman dan caranya masing-masing. Budidaya yang dilakukan petani kopi rakyat tidak ada Standar Operational Procedure (SOP) yang diikuti dan mengikat. Dari subak juga tidak ada instruksi untuk menerapkan SOP yang sama untuk diterapkan petani kopi rakyat. SOP hanya dilakukan ketika panen petik merah untuk memenuhi mutu sesuai dengan kebutuhan pasar. Petani kopi rakyat tidak melakukan perencanaan namun selalu mengusahakan agar tidak rugi berdasarkan pada pengalaman. Pengalaman tersebut membuat petani bisa membaca situasi lapang untuk selalu mengusahakan dengan maksimal. Usaha yang dilakukan petani dari segi mutu kopi, pemupukan, pemeliharaan, panen dan pemasaran. Sedangkan untuk modal, petani kopi rakyat tidak memiliki modal yang banyak dan hanya bergantung pada hasil penjualan serta modal kepercayaan. Sistem budidaya kopi yang dilaksanakan petani berdasarkan modal yang dimiliki. Modal tambahan dari subak dengan iuran wajib setiap bulan sebesar Rp5.000,setiap anggota. Ada juga tambahan modal bersumber dari Kredit Usaha Rakyat (KUR). Biasanya menggarap lahan sendiri kecuali jika ada modal berlebih menyewa tenaga kerja untuk menggarap lahan.

Kebutuhan pelatihan petani kopi rakyat saat ini utamanya ada di budidaya seperti pembibitan, pemeliharaan serta pengendalian hama dan penyakit. Penyuluh pertanian seperti di Batukaang yang dikirim dari Bangli dinilai kurang kompeten dalam 
membina petani karena tidak bisa menyelesaikan permasalahan hama dan penyakit pada kopi. Hal tersebut terjadi karena faktor manajemen kelembagaan penyuluhnya yang kurang baik. Pengendalian penyakit dilakukan atas inisiatif petani kopi rakyat dengan menebang bagian yang terserang dan langsung membakarnya. Saat ini petani tidak mau menerima bantuan bibit dari pemerintah karena kualitas bibit yang diberikan tidak sesuai dengan kondisi tanah dan lingkungan yang dimiliki petani. Bibit dengan varietas unggul seperti sigararutang yang diberikan pemerintah tidak dapat tumbuh dengan baik di lahan milik petani kopi rakyat. Petani lebih memilih bibit yang mereka punya dengan menyesuaikan kondisi lingkungan dan topografinya. Akhirnya petani hanya menanam bibit pemberian dari pemerintah untuk lahan uji coba.

\section{Subak}

Subak merupakan sebutan kelompok tani di Bali dengan ikatan hierarkis antara adat dan pemerintahan. Subak mengatur sistem pengelolaan pertanian, rancangan upacara keagamaan, hubungan interaksi antara anggota atau petani dengan investor atau pemerintahan. Adanya subak mengikat solidaritas hubungan sosial humanis dengan internal warga atau anggotanya. Semua anggota masyarakat yang sudah menikah dan memiliki lahan pertanian atau menggarap lahan pertanian otomatis menjadi anggota subak. Satu desa minimal terdiri dari satu subak yang dipimpin oleh klien subak. Klien subak merupakan seseorang yang dianggap memiliki kemampuan lebih dalam memimpin dan mengayomi anggotanya.

Subak merupakan organisasi atau kelompok tradisional dalam bidang pengelolaan pertanian di tingkat usaha tani pada masyarakat adat di Bali yang bersifat sosioagraris, religius, ekonomis yang secara historis terus tumbuh dan berkembang. Subak berasaskan Pancasila, UUD 1945 dan konsep Tri Hita Karana dijiwai Hindu. Tri Hita Karana secara inflisit mengandung pesan agar masyarakat dapat mengelola sumber daya alam termasuk air secara arif untuk menjaga kelestarian, senantiasa bersyukur kepada Tuhan Yang Maha Esa dan selalu mengedepankan harmoni serta kebersamaan dalam memecahkan masalah. Tujuan subak diantaranya memelihara dan melestarikan organisasi subak, mensejahterakan kehidupan petani, mengatur pengairan dan tata tanaman, melindungi dan mengayomi petani, serta memelihara serta memperbaiki saluran air ke sawah atau lahan pertanian. ${ }^{24}$

Tatanan hidup di Bali sudah berjalan harmonis dan melekat dalam kehidupan sehari-hari masyarakatnya. Masyarakat Bali cenderung menikmati dan mengambil hal positif terhadap adat istiadat yang ada. Adat istiadat memberikan hubungan masyarakat menjadi lebih erat, kompak dan disiplin lebih tinggi. Dari remaja, dewasa hingga tua menerapkan nilai-nilai kedisiplinan. Semuanya bekerja keras tanpa melihat laki-laki atau perempuan dimulai dari pagi hingga sore. Ketika ada masalah yang terjadi diselesaikan menggunakan musyawarah kekeluargaan. Hukum adat diterapkan jika dengan musyawarah belum terselesaikan. Upacara adat yang dilakukan petani berupa

${ }^{24}$ Peraturan Daerah Provinsi Bali. (2012). Peraturan Daerah Provinsi Bali No. 9 Tahun 2012. Gubernur Bali. Denpasar. 
tumpek wariga. Tumpek wariga merupakan sembayang di pura dan di kebun bersamaan dengan alat-alat pertanian. Budaya bersih kebun menjelang hari raya yang berdampak pada kebersihan kebun dari kotoran dan rumput.

\section{Sejarah Kemitraan}

Sekitar tahun 2013 kopi dimonopoli oleh pihak pabrik kopi Mengani dengan mematok harga rendah. Awalnya subak diikat kontrak dengan pabrik Mengani untuk menjadi pemasok utama kopi disaksikan Dinas Pertanian Bangli. Kontrak yang kurang jelas menyebabkan petani kopi rakyat dirugikan. Saat puncak panen dan produksi kopi melimpah, pabrik Mengani hanya mau menerima petikan dengan mutu yang baik. Sedikit petikan yang mutunya kurang baik membuat pabrik Mengani tidak menerima dan langsung mengembalikan kepada petani kopi rakyat tanpa adanya komunikasi yang baik. Tindakan tersebut menimbulkan harga kopi yang menurun secara signifikan dan menyebabkan kerugian besar dirasakan petani kopi rakyat. Hal tersebut disebabkan karena tidak adanya komunikasi yang baik terkait standar mutu kopi dan penentuan harga.

Harga jual kopi yang rendah membuat petani kopi rakyat frustrasi dalam budidaya kopi. Selama ini dalam penentuan harga, petani kopi rakyat hanya mengikuti pasar dan nilai tawar pembeli atau pengepul lokal. Negosiasi dilakukan antara petani kopi rakyat dan pengepul lokal atau tengkulak untuk menentukan harga. Harga yang ditawarkan pengepul lokal terbilang rendah dan bahkan pernah mencapai Rp3800,-/kg. Pemasaran ke pengepul lokal tidak ada standar mutu dan tidak ada pengontrolan. Bahan baku kopi dalam bentuk apapun diterima oleh pengepul lokal. Sebelum masa panen raya, harga kopi cenderung mahal karena permintaan meningkat. Saat panen raya harga kopi mulai stabil saling bersaing pemasaran dalam bentuk gelondong. Secara keseluruhan harga kopi terbilang fluktuatif atau naik turun tergantung permintaan dan penawaran.

Peristiwa kelam membuat petani kopi rakyat mulai menerapkan pola pemasaran secara mandiri. Kegiatan pemasaran yang dilakukan petani kopi rakyat mengikuti harga pasar dan pengepul lokal. Tidak ada sistem kontrak dengan siapapun. Petani kopi rakyat lebih memilih sistem kemitraan yang tidak mengikat namun saling menguntungkan. Pengalaman masa lalu juga yang membuat petani tidak ada yang menerapkan sistem kontrak dalam pemasaran. Pemasaran kepada pengepul lokal sekitar biasanya membuat harga rendah dan dipermainkan. Petani melihat pasar yang bisa menerima pasokan bahan baku secara kontinyu seperti Kebun Blawan. Meskipun harga yang ditawarkan tidak terlalu tinggi, namun Kebun Blawan dapat menyerap produksi kopi rakyat dengan kuantitas yang besar dan terdapat negosiasi yang tidak merugikan. Hal tersebut membuat petani kopi rakyat memilih Kebun Blawan sebagai mitra.

Selain itu, petani kopi rakyat Kintamani dan Kebun Blawan sudah memiliki hubungan emosional sejak dahulu. Bibit kopi yang tertanam di wilayah Kintamani sejarahnya dalam merupakan bantuan yang diberikan oleh PT. Perkebunan Nusantara 
XXVI (sekarang PT. Perkebunan Nusantara XII) sekitar tahun 1979. Hal tersebut diperkuat dengan sejarah perusahaan yang dulu pernah memiliki pabrik pengolahan di Kintamani Bali sekitar tahun 1992. Hingga akhirnya sekitar tahun 1994 PT. Perkebunan Nusatara XII menyerahkan sepenuhnya pengelolaan pabrik kepada pemerintah Kabupaten Bangli. Kemitraan mulai dibangun kembali pada tahun 2019 yang merupakan penunjukan langsung dari holding PTPN Group melalui Kebun Blawan milik PT. Perkebunan Nusantara XII.

Kopi kintamani memang sudah dikenal memiliki beberapa keunggulan yang menyebabkan Kebun Blawan tertarik untuk melakukan kemitraan. Awalnya perusahaan datang menemui Ni Wayan Ariani sebagai koordinator pemasaran untuk minta sampel kopi. Ni Wayan Ariani dikenal sebagai pengepul besar di Desa Batukaang, Kecamatan Kintamani, Kabupaten Bangli. Selanjutnya petani kopi rakyat sekitar Desa Batukaang diundang oleh perusahaan dalam rangka pemaparan program kemitraan sekaligus pemberian spesifikasi terkait petikan dan tawaran harga yang sesuai dengan pasar. Kesepakatan kemitraan terjadi antara perusahaan dengan petani kopi rakyat melalui Ni Wayan Ariani sebagai koordinator pemasaran. Terbentuknya kemitraan petani kopi rakyat dengan perusahaan bertujuan menghindari monopoli pengepul lokal agar tercipta persaingan sehat. Kedatangan perusahaan berdampak pada harga pasar kopi yang perlahan mulai stabil.

\section{Kondisi Kemitraan}

Kemitraan yang dilakukan perusahaan dengan petani kopi rakyat merupakan wujud implementasi dari program BUMN untuk Indonesia. Program ini dibentuk untuk menciptakan sinergitas antar BUMN yang ada di Indonesia dalam pelaksanaan PKBL dan CSR kepada masyarakat. Sistem kemitraan yang terbentuk antara Kebun Blawan dengan petani kopi rakyat berupa sistem kemitraan bersama antara kebun, petani dan BNI. Kemitraan dengan petani kopi rakyat membutuhkan pendanaan yang cukup besar. Sedangkan target pada tahun 2020 suplai kopi hard skin dari petani kopi rakyat Kintamani sekitar 300 ton atau sama dengan 2000 ton gelondong merah. Kemitraan dengan petani kopi rakyat merupakan bagian dari Program Kemitraan atau PK. Keterbatasan dana PK yang dimiliki perusahaan tersebut membuat penyaluran dana dialihkan melalui sinergi dengan BNI. Pembelian kopi rakyat dilakukan oleh Kebun Blawan dengan BNI melalui dana Kredit Usaha Rakyat (KUR) kepada petani kopi rakyat.

Gambar 1. Bagan Pola Kemitraan Inti Plasma

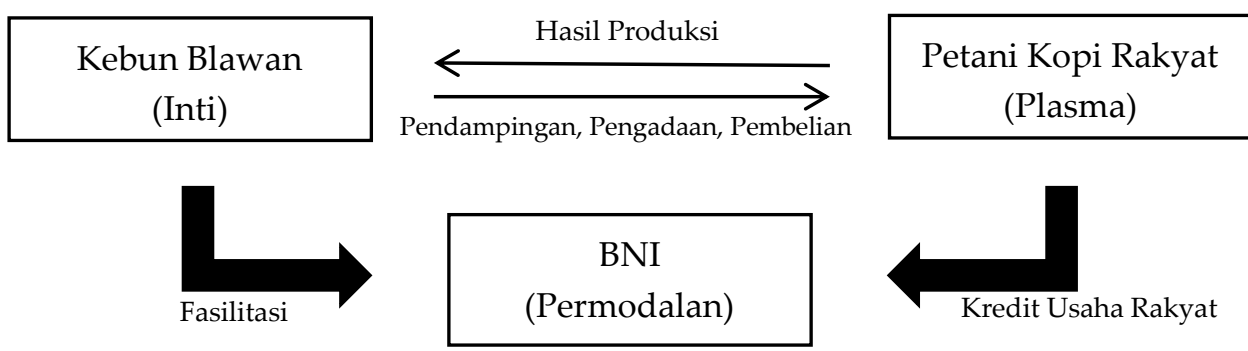


Model kemitraan ini termasuk mutualistik karena kerjasama antara tiga pihak yang saling menyadari untuk saling memberikan manfaat dalam bermitra sehingga tercapai tujuan bersama secara optimal. ${ }^{25}$ Berdasarkan bagan pola kemitraan inti plasma yang terbentuk terdapat tiga pihak yang berhubungan antara perusahaan, petani kopi rakyat dan BNI. Perusahaan sebagai perusahaan inti memberikan fasilitas pendampingan, pengadaan dan pembelian kepada petani kopi rakyat sebagai plasmanya. Disamping itu petani kopi rakyat sebagai plasma memiliki kewajiban memberikan hasil produksi kopinya kepada perusahaan inti. Pembelian hasil produksi kopi oleh perusahaan inti melibatkan BNI sebagai pihak yang menyalurkan pinjaman modal berupa Kredit Usaha Rakyat (KUR) kepada plasma.

Sebagai perusahaan profesional, Kebun Blawan belum melaksanakan pendampingan dan pemberdayaan secara intensif kepada petani kopi rakyat Kintamani. Pendampingan dilakukan hanya sekadar untuk memberikan pengarahan terkait keseragaman mutu agar sesuai standar ketetapan ekspor kopi arabika. Selain itu, perusahaan hanya membeli kopi gelondong superior saat puncak panen dan biji kopi HS (Hard Skin) saat panen mulai menyusut. Kejelasan sistem kerjasama Program Kemitraan dan Bina Lingkungan (PKBL) dari perusahaan kepada petani kopi rakyat Kintamani juga belum mencapai kesepakatan. Hal tersebut berdampak pada supplay kopi arabika dari petani kopi rakyat Kintamani kepada perusahaan menjadi belum optimal.

Aktivitas perusahaan dalam melakukan kemitraan dengan petani kopi rakyat Kintamani merupakan usaha dalam mempertahankan produksi untuk memenuhi kebutuhan pasar dunia. Hal ini terjadi karena hubungan yang dilakukan sebatas memenuhi produksi kopi perusahaan yang rendah dan belum adanya upaya dalam memberdayakan petani kopi rakyat untuk lebih berkembang dan mandiri. Kondisi seperti ini mewujudkan ekonomi yang tidak seimbang disebut dualisme ekonomi. ${ }^{26}$ Dualisme ekonomi terjadi karena petani kopi rakyat Kintamani tidak didorong untuk menjadi petani kopi rakyat yang mandiri untuk kemajuannya sendiri. Sebaliknya petani kopi rakyat Kintamani seakan-akan dituntut memasarkan pasokan kopi untuk memenuhi kebutuhan pasar perusahaan.

Petani kopi rakyat menyediakan kopi dengan mutu yang di inginkan oleh perusahaan. Usaha dilakukan petani kopi rakyat dengan menjaga mutu yang baik agar hasil produksinya dapat diterima oleh perusahaan. Syarat mutu yang baik kopi gelondong berwarna merah dan tidak busuk. Petani kopi rakyat harus bisa menyesuaikan standar mutu yang diberikan oleh perusahaan karena standar mutu yang diberikan dengan pasar yang ada di Bali berbeda. Sebelumnya petikan petani tidak seragam atau hanya asal petik, biasanya sepertiga hijau. Semenjak bermitra dengan perusahaan, petani mulai terbiasa petik merah dan lebih baik dalam menjaga mutu.

Perusahaan mengutamakan mutu kopi yang dimiliki petani kopi rakyat sesuai dengan kebutuhan perusahaan. Oleh karena itu, petani kopi rakyat harus menyiapkan

\footnotetext{
${ }^{25}$ Sulistyani, Op.cit

${ }^{26}$ Boeke, J., H. (1953). Economics and economic policy of dual societies; as exemplified by Indonesia. Harlem: H.D Tjeenk Willink N.V.
} 
dengan maksimal mutu yang diharapkan perusahaan. Mayoritas petani kopi rakyat menyuplai hasil kopi miliknya berbentuk gelondong ke perusahaan. Sisanya mengelola kopi dengan sistem olah basah misalnya berbentuk kopi luwak. Harga penjualan gelondong oleh perusahaan bulan September 2020 cukup tinggi dari pengepul lokal yaitu sebesar Rp7500/kg artinya selisih Rp200,- karena sebelumnya harga tidak ada yang sampai segitu. Meskipun harga yang ditawarkan tinggi, harga gelondong kopi saat ini tergolong paling rendah dibanding bulan lalu yang bisa mencapai Rp8200/kg. Turunnya harga disebabkan karena faktor pasar dunia sedang turun dan kualitas serta mutu petikan petani yang menurun akibat pandemic Covid-19.

Komunikasi dan garis koordinasi antara petani kopi rakyat dengan perusahaan sejauh ini baik, lancar dan transparan. Selalu terjadi negosiasi antara petani kopi rakyat dan perusahaan dalam menentukan harga kopi. Negosiasi tersebut didasarkan pada permintaan dan harga pasar atau penawaran yang dilakukan oleh pengepul lokal kepada petani kopi rakyat. Selama harga masih standar pasar dan tergolong stabil terjadilah kesepakatan. Kesepakatan dilakukan antara petani kopi rakyat dengan perusahaan melalui koordinator pemasaran atau Ni Wayan Ariani. Koordinasi yang biasa dilakukan secara bertahap utamanya terkait harga dan kualitas petikan. Ketika ada hasil pengiriman petikan gelondong dari petani yang kurang bagus, perusahaan tetap melakukan konfirmasi kepada para petani melalui Ni Wayan Ariani untuk meningkatkan mutu kopinya. Pernah terjadi keterlambatan pembayaran namun sudah dapat diselesaikan dengan baik.

Selama ini petani memasarkan kopi tidak menggunakan izin usaha. Dari pemerintah atau petugas dinas setempat tidak ada pengecekan. Petani kopi rakyat hanya sekadar menyetock bahan baku saat selesai masa panen seperti pembuatan kopi luwak dengan sasaran wisatawan. Biasanya petani memasarkan hasil panennya $70-80 \%$ berbentuk gelondong, 20\% berbentuk green beans, $8 \%$ berbentuk kopi luwak dan $2 \%$ berbentuk bubuk. Pemasaran utama dalam bentuk gelondong salah satunya disebabkan karena belum adanya izin usaha. Petani juga tidak pernah melakukan promosi. Selebihnya hanya dijual melalui koordinator pemasaran ke perusahaan. Koordinator pemasaran melakukan ekspansi mengambil bahan baku kopi petani dan memasarkan kepada perusahaan.

Secara letak geografis, perusahaan memiliki wilayah yang cukup strategis karena berada pada wilayah bagian objek wisata pegunungan Ijen. Tempat yang strategis menjadi daya tarik bagi wisatawan berkunjung ke perusahaan yang juga memiliki agrowisata berupa niagara mini dan pemandian air panas. Disisi lain, sasaran pemasaran kopi arabika di Bali salah satunya pada sektor pariwisata. Bali memiliki berbagai objek wisata yang selalu ramai dikunjungi wisatawan lokal dan mancanegara. Wisatawan lokal dan mancanegara menjadi sasaran utama produk kopi dalam bentuk seduhan seperti kopi luwak. Harga satu cangkir kopi luwak yang dijual kepada wisatawan dapat mencapai Rp150.000,--

Pandemic Covid-19 berdampak besar bagi perekonomian masyarakat tidak terkecuali petani kopi rakyat Kintamani. Saat masa Covid-19 permintaan kopi menurun menyebabkan harga jual kopi menurun yang tadinya Rp10.000,-/kg menjadi Rp7.000,- 
/kg untuk kopi gelondong. Petani kopi rakyat menerapkan protokol kesehatan dengan menjaga jarak saat petik kopi. Covid-19 juga berdampak pada sektor pariwisata karena tidak adanya wisatawan yang datang ke Bali tentu mengakibatkan tidak lakunya pemasaran dalam bentuk seduhan kopi seperti kopi luwak. Isu dunia berupa pandemic Covid-19 juga berpengaruh pada perusahaan. Berdasarkan instruksi dari pemerintah, usaha hotel ditutup dan agrowisata milik perusahaan menjadi terhenti dengan tidak adanya wisatawan yang datang dan biaya yang tetap bertambah karena tenaga kerja yang masih masuk. Kegiatan produksi tetap jalan dengan catatan karyawan mengikuti arahan dari pemerintah untuk tetap menjaga kebersihan dan menjaga sistem imun.

\section{Teknis Pelaksanaan Kemitraan}

Petani kopi rakyat sudah lama bekerjasama dengan koordinator pemasaran dan memiliki loyalitas tinggi. Loyalitas tersebut ditandai dengan selama bekerjasama dengan koordinator pemasaran dilaksanakan tidak ada masalah dan kendala yang dirasakan petani. Koordinator pemasaran dapat mengayomi dengan baik para petani melalui subak dalam pemasaran kopi. Pembinaan dilakukan oleh koordinator pemasaran kepada petani dalam jangka waktu 2-3 hari sekali selama panen raya. Koordinator pemasaran memberikan pengarahan dan mendatangi langsung petani untuk petik merah dalam kondisi yang segar. Sejauh ini program hanya berfokus pada pengembangan mutu kopi petani. Disisi lain petani kopi rakyat merasa aman dengan hadirnya koordinator pemasaran yang selalu membeli kopinya. Petani selalu mengusahakan lancar dan tepat waktu dalam memasok bahan bakunya ke koordinator pemasaran.

Ada sepuluh desa sekitar Kintamani atau subak yang bermitra dengan Kebun Blawan. Desa tersebut diantaranya Batukaang, Mengani, Catur, Awan, Bonyoh, Ulian, Pelaga, Sukawana, Belantih dan Bayung Gede. Pasokan kopi terbanyak dari Desa Batukaang dan Desa Mengani karena jarak yang dekat dan rutinitas dalam memasok. Sedangkan Desa Pelaga menjadi daerah terjauh sekaligus sulit untuk mengambil pasokan kopi karena bersaing dengan pengepul lokal yang ada disana. Petani yang bekerjasama dan menyuplai kopi ke perusahaan kurang lebih sebanyak 200 orang. Setiap subak atau desa rata-rata sebanyak 20 petani. Proses pengiriman gelondong dari petani ke Kebun Blawan tahun ini dilakukan setiap hari dimulai dari 1 April 2020 hingga 10 Oktober 2020 dengan total produksi 3.397 ton.

Alur distribusi kopi petani kopi rakyat berawal dari pemetikan pada pagi hari, pengemasan siang hari, pengumpulan sore hari dan pengiriman malam hari. Setelah bahan baku dikemas dengan baik langsung dikirimkan melalui koordinator pemasaran. Pengiriman bahan baku dilakukan dalam kondisi yang segar dan tidak bisa disimpan dalam jangka waktu beberapa hari. Bahan baku yang dikirim monitoring setiap penggal proses. Bagian pengatur barang memantau pengiriman bahan baku dari petik hingga pelaporan. Pernah terjadi pengiriman bahan baku yang tidak tepat waktu karena kurangnya transportasi untuk mengangkut dan peraturan sistem jasa transportasi kapal yang rumit. Jarak antara Kintamani ke Blawan yang cukup jauh dan memerlukan waktu sekitar 7-9 jam membuat truk pengangkut harus dapat sampai tepat waktu dalam 
pengiriman bahan baku kopi. Truk pengangkut harus melewati Selat Bali dengan menggunakan jasa transportasi kapal. Pandemic Covid-19 menimbulkan peraturan baru pada jasa transportasi kapal yang berdampak pada lamanya proses mobilisasi. Keterlambatan pengiriman bahan baku menyebabkan menurunnya mutu kopi. Kunci proses pengiriman ada pada ketepatan waktu.

Gambar 2. Alur Distribusi Kopi Arabika Petani Kopi Rakyat

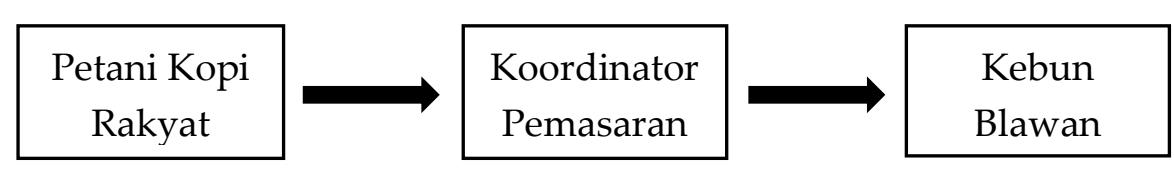

Selama ini sistem kemitraan yang terjalin tidak melibatkan koordinasi ketua subak. Alhasil tidak adanya kontrak yang mengikat dengan subak dan petani kopi rakyat namun kemitraan berjalan dengan sistem kepercayaan. Semenjak ada kemitraan dengan perusahaan tanpa ada kontrak yang mengikat, bahan baku kopi bisa diserap optimal. Petani kopi rakyat juga memilih sistem pembayaran tunai dalam sistem pembayarannya, artinya ketika ada barang langsung dibayarkan. Harga yang murah menjadi tidak sesuai harapan petani karena kualitas yang menurun, maka perusahaan dapat memberikan pelatihan mengenai tahapan dalam meningkatkan mutu yang dihasilkan. Harga yang kurang objektif karena baru mengirimkan hasil rendemen satu pekan setelah dikirim ke pabrik, maka perusahaan dapat memberikan informasi rendemen secara transparan dan lebih cepat. Mekanisme pembayaran melalui transfer bank belum memberikan kemudahan karena petani jauh dari bank, maka perusahaan dapat membayar secara tunai. ${ }^{27}$

\section{Keberlanjutan Kemitraan}

Program pengendalian kualitas perusahaan dapat dilakukan menjadi lebih baik dan biaya kegagalan internal dan eksternal menurun, jika aktivitas pengendalian yang terdiri dari aktivitas pencegahan dan penilaian lebih efektif. Penilaian dapat menemukan adanya produk cacat, dan pencegahan dapat mencegah terjadinya produk cacat. Program pengendalian kualitas perusahaan dapat dilakukan menjadi lebih baik dan biaya kegagalan internal dan eksternal menurun, jika aktivitas pengendalian yang terdiri dari aktivitas pencegahan dan penilaian lebih efektif. Penilaian dapat menemukan adanya produk cacat dan pencegahan dapat mencegah terjadinya produk cacat. Laporan membantu manajer untuk memahami pentingnya biaya kualitas, titik area permasalahan dan cara biaya kualitas didistribusikan. ${ }^{28}$

${ }^{27}$ Faishol, M., I. (2015). Pengaruh harga beli tebu, kualitas layanan dan reputasi perusahaan terhadap keputusan petani untuk menjual tebu di pabrik gula rendeng Kudus. J. Sains Pemasaran Indonesia. 17(2): 184202.

${ }^{28}$ Runtuwene, J., N., Ventje, I., \& Natalia, G. (2019). Analisis penentuan biaya kualitas produk pada PT. Tropica Cocoprima. J. Riset Ekonomi, Manajemen, Bisnis dan Akuntansi. 7(4): 4868-4877. 
Pabrik Mengani milik pemerintah Bangli saat ini sudah tidak berjalan. Rencana selanjutnya Kebun Blawan dan petani kopi rakyat bekerjasama agar dapat menggunakan tempatnya sebagai pengolahan gelondong kopi petani. Rencana tersebut sebagai tindak lanjut proses pengolahan gelondong menjadi kopi pasar untuk mengurangi risiko pengiriman. Kelemahan pengiriman dalam bentuk gelondong mudah busuk jika tidak segera di proses. Kopi pasar memberikan hasil maksimal agar tidak terjadi fermentasi saat pengiriman, mutunya dapat terjamin, memuat hasil lebih banyak dan menekan biaya. Target tahun depan panen bisa melimpah agar bisa terus menyuplai kopi ke perusahaan. Jika petikan segar dan mutu sesuai kemitraan tetap berjalan dengan lancar.

Kualitas produk yang dihasilkan perusahaan ditentukan dengan jumlah biaya yang dikeluarkan. Maka efisiensi biaya dalam sistem usaha sangat diperlukan untuk menunjang kualitas produk yang dihasilkan. Perusahaan harus bisa meminimalisir adanya peningkatan biaya dengan strategi pengendalian dan pencegahan terutama yang berkaitan dengan petani kopi rakyat sebagai mitra. Pembinaan kepada petani kopi rakyat dengan cara melakukan pengolahan secara langsung dapat meminimalisir biaya yang dikeluarkan dan meningkatkan pendapatan keduanya. Strategi ini bertujuan agar perusahaan mampu memiliki pabrik pengolahan bertempat di wilayah kebun milik petani sehingga suplai produk kepada perusahaan dapat optimal dari segi kualitas ataupun kuantitas.

Tabel 1. Matriks Keunggulan dan Kelemahan Keberlanjutan Kemitraan

\begin{tabular}{|c|c|}
\hline Keunggulan & Kelemahan \\
\hline $\begin{array}{l}\text { - Menekan biaya pengiriman dan } \\
\text { meningkatkan hasil produksi sehingga } \\
\text { kuantitas yang dikirim ke perusahaan } \\
\text { lebih banyak }\end{array}$ & $\begin{array}{l}\text { - Perlunya waktu untuk mengeratkan } \\
\text { hubungan semua stakeholders yang } \\
\text { ada di wilayah petani kopi rakyat }\end{array}$ \\
\hline $\begin{array}{l}\text { - Mutu hasil produksi yang dikirim ke } \\
\text { perusahaan menjadi lebih baik }\end{array}$ & \\
\hline $\begin{array}{l}\text { - Membuka lapangan pekerjaan baru untuk } \\
\text { pabrik pengolahan }\end{array}$ & \\
\hline
\end{tabular}

Sumber: Analisis Data Primer 2020

\section{KESIMPULAN}

Kemitraan dengan perusahaan berjalan lancar dan tidak kendala. Sudah satu tahun kemitraan berjalan sejak bulan Juli 2019. Dampak kemitraan dengan perusahaan yang dirasakan petani kopi rakyat seperti lancarnya pemasaran kopi. Harapan petani kemitraan bisa kontinyu dan dilaksanakan dalam jangka panjang. Selain itu agar petani tidak terkendala perihal keuangan dan terus timbul semangat untuk budidaya kopi. Ada juga harapan petani kepada Kebun Blawan untuk diberikan pembinaan yang lebih 
intensif, saling membantu dan diberikan bantuan alat lagi. Pemberian bantuan alat berupa pulper dibutuhkan petani untuk proses pembuatan biji kopi pasar (HS). Jadi petani tidak perlu meminjam dan hubungan dengan perusahaan semakin erat.

Kesadaran dalam kemitraan perlu dikuatkan dari masing-masing pihak agar hubungan yang tercipta dapat saling menguntukan dan tidak hanya merugikan satu pihak. Salah satu faktor yang mempengaruhi kepercayaan petani kopi rakyat untuk terus bermitra dengan perusahaan adalah penetapan harga. Petani menginginkan kestabilan harga yang diberikan oleh perusahaan. Semakin tinggi harga produk yang ditetapkan perusahaan maka semakin meningkat juga kepercayaan petani terhadap perusahaan. Sebaliknya perusahaan menginginkan petani memberikan hasil panen dengan standar mutu yang sesuai. Upaya untuk menyeragamkan mutu dan kualitas dilakukan oleh perusahaan kepada petani dengan melakukan pembinaan.

\section{REFERENSI:}

Boeke, JH. (1953). Economics and economic policy of dual societies; as exemplified by Indonesia. Harlem: H.D Tjeenk Willink N.V.

Dinas Perkebunan Bali. (2015). Kopi Arabika Kintamani Masuk Unggulan Komoditi Nasional [Internet]. Available from: http://www.disbun.baliprov.go.id/berita/detail/74-kopi-arabika-kintamanimasukunggulan-komoditi-nasional

Direktorat Jenderal Peningkatan Mutu Pendidik dan Tenaga Kependidikan Departemen Pendidikan Nasional. (2008). Pendekatan, Jenis, dan Metode Penelitian Pendidikan. Jakarta.

Faishol, MI. (2015). Pengaruh harga beli tebu, kualitas layanan dan reputasi perusahaan terhadap keputusan petani untuk menjual tebu di pabrik gula rendeng Kudus. Jurnal Sains Pemasaran Indonesia. 17(2): 184-202.

Imang, N., Balkis, S, \& Maliki. (2019). Analisis implementasi pola kemitraan dan pendapatan petani plasma kelapa sawit di Kecamatan Bentian Besar Kabupaten Kutai Barat Provinsi Kalimantan Timur. Jurnal Pertanian Terpadu. 7(1): 112-121.

International Coffee Organization. (2016). Monthly Coffee Market Report. 13 September 2019, dapat diakses online di http://www.ico.org.

Lukman, IA; Munawar, I; Dwi, B. (2019). Palm oil plantation partnership's performance in Kuantan Singingi Region. The International Journal of Accounting and Business Society. 27 (2): 92-113.

Mawardi S; Wibawa A; Avelino J; Perriot J-J; Jacquet M; Sautier D; De Taffin G; Sallée

B; Lelong C; Ribeyre F. (2005). Developing a geographical indication for Arabica 
coffee in Bali : Description of the "Terroir" of Kintamani. 20th Int Conf Coffee Sci.: 922-928.

Miles, BM; M, Huberman. (1992). Analisis Data Kualitatif Buku Sumber Tentang Metodemetode Baru. Jakarta: UIP.

Moleong, LJ. (2018). Metodologi penelitian kualitatif. Bandung: PT Remaja Rosdakarya Offset.

MPIG. 2007. Buku Persyaratan Indikasi Geografis Kopi Arabika Kintamani Bali.

Pemerintah Indonesia. (2008). Undang-Undang No. 20 Tahun 2008 tentang Usaha Mikro, Kecil dan Menengah. Lembaran Negara RI Tahun 2008 No. 93. Sekretariat Negara. Jakarta.

Peraturan Daerah Provinsi Bali. (2012). Peraturan Daerah Provinsi Bali No. 9 Tahun 2012. Gubernur Bali. Denpasar.

Pusat Data dan Sistem Informasi Pertanian. (2017). Outlook kopi (komoditas pertanian sub sektor perkebunan). Jakarta.

Pusat Data dan Sistem Informasi Pertanian. (2019). Outlook kopi (komoditas pertanian sub sektor perkebunan). Jakarta.

Rathi, D; Given, LM; Forcier, E. (2014). Interorganisational partnership and knowledge sharing: the perspective of Non-Profit Organizations (NPOs). Journal of Knowledge Management. 18(5): 867-885.

Rubiyo; Kartini L; Agung IMS. (2005). Pengaruh Dosis Pupuk Kandang dan Lama Fermentasi terhadap Mutu Fisik dan Citarasa Kopi Arabika Varietas S 795 di Bali. Jurnal Pengkajian dan Pengembangan Teknologi Pertanian. 8:250-260.

Runtuwene, JN; Ventje, I; Natalia, G. (2019). Analisis penentuan biaya kualitas produk pada PT. Tropica Cocoprima. Jurnal Riset Ekonomi, Manajemen, Bisnis dan Akuntansi. 7(4): 4868-4877.

Sumardjo; Sulaksana, J; Darmono, W. (2004). Teori dan praktik kemitraan agribisnis. Jakarta. Penebar Swadaya.

Sulistiyani, AT. (2004). Kemitraan dan model-model pemberdayaan. Yogyakarta: Gava Media.

Yusuf, AM. (2017). Metodologi penelitian kuantitatif, kualitatif $\mathcal{E}$ penelitian gabungan. Jakarta: Prenademedia Group. 
Wahyuni E; Karim A; Anhar A. (2013). Analisis Citarasa Kopi Arabika Oganik pada Beberapa Ketinggian Tempat dan Cara Pengolahannya di Dataran Tinggi Gayo. Jurnal Manajemen Sumberdaya Lahan. 2(3).

Widia, IW; Duniaji, AS. (2016). Laporan pelaksanaan rencana aksi pengembangan industri agro kopi di Propinsi Bali tahun 2016. Bali : Dinas Perindustrian dan Perdagangan Propinsi Bali dan Fakultas Teknologi Pertanian Universitas Udayana.

Yahmadi, M. (2007). Rangkaian perkembangan dan permasalahan budidaya dan pengolahan kopi di Imdonesia. Surabaya: AEKI. 